\title{
Literárnohistorický výskum: generácie a osobnosti
}

\author{
Viera Žemberová (Prešov)
}

Karol Csiba: Privátne, verejné, autobiografické (v memoároch a publicistike Mila Urbana, Jána Smreka, Jána Poničana, Tida J. Gašpara). Bratislava: Ústav slovenskej literatúry SAV, 2014. 165 s. ISBN 978-80-8874626-3.

Ivan Kadlečík: Iskra v studenej pahrebe. Besedy a besednice. Levice: KK Bagala, 2012. 116 s. ISBN 97880-8108-062-3.

Výskum uchovaného alebo sprístupneného materiálu, dokumentov, písomností rozličného významu a s odlišnou iniciáciou ich vzniku prináša do literárnej histórie jednak návrat ku konkrétnej osobnosti, Ivanovi Kadlečíkovi, alebo sa usiluje o návraty či o obnovenie a rozšírenie aj spresnenie dostupného poznania nová skupina bádatelov, a to prináša publikácia Karola Csibu. Nech už ide o osobnosṫ a jej neprehliadnutelné vstupovanie do dobového kultúrneho a literárneho života, alebo o sondu z generačného vyrovnávania sa $\mathrm{s}$ uchovaným materiálom, napokon sa výstupom stane potrebný a nie raz aj podnetný návrat do súvislostí a príčinný následok dobového kontextu, ktorým sa vymedzuje, alebo obmedzuje účinkovanie jednotlivca alebo generácie v literárnom spoločenstve.

Literárna história dostala z doterajšieho publikovaného výskumu viaceré podnety na sondovanie v minulom storočí, teda v tom, čo utváralo jeho kultúrne a literárne dejiny, generačné koncepcie, pohyby v genológii a v osobnostnom postoji tých, ktorí vstupovali z rozličných príčin po prvý raz, či znova v posledných desatročiach do literárneho aj do širšie chápaného kultúrneho života. Literárnohistoricky, literárne a esejisticky spracované a zverejnené výskumné sondy do tých dejov, ktoré z odstupu prirodzene plynúceho času si prirodzene žiadajú aktualizovaný výklad, sú zastúpené prácami z komparujúceho záberu Karola Csiba, alebo sa dožadujú, napokon tak sa rozhodol Ivan Kadlečík, rekonštrukcie a doplnkov do obsahu toho času, čo sa uchoval v jeho pamäti a z jeho vôle aj vo zverejnených tlačiach.
„... s pojmom memoáre pracujem zámerne vol’nejšie... “ (Karol Csiba)

Vývinová štruktúra minulého storočia $\mathrm{v}$ dejinách slovenskej literatúry a literárnej vedy sa prirodzene pre nové bádatel'ské generácie stala školou metodológie, ale aj prostého vedenia o tom, čím tvorba, autor, čitatel a spoločnost prechádzali na pozadí vážnych spoločenských a politických pohybov. Po tomto podnete sa výskum z prepojeného kontextu aj javu mení na školu relevantných odborných výstupov pre generácie tých, ktorí sa rozhodli utvárat modernú, rozumej fundovanú prítomnost' literárnej histórie a širšie uskutočnit svoj zámer a precizovat kultúrne vedomie svojich rovesníkov.

Čas utvára aj optimálne podmienky pre literárneho historika, ktorý má blízko k dokumentom a nie raz aj $\mathrm{k}$ ich tvorcom. Návraty $\mathrm{k}$ dostupným výstupom dobovej literárnej kritiky a do syntéz adaptovanej literárnej histórie sa odvíjajú od prirodzených posunov v metodológii voči jej aplikáciám uplatňovaným generáciou predchodcov, čím prinášajú pre súčasného záujemcu o poznanie kontextu či kontinuity vo vedeckom a kultúrnom povedomí zaujímavé až neočakávané podnety.

Pre publikáciu Privátne - verejné - autobiografické (v memoároch a publicistike Mila Urbana, Jána Smreka, Jána Poničana, Tida J. Gašpara) vytvorila literárna história vhodné iniciačné podnety, ktorých sa ujal Karol Csiba, súc si vedomý jedinečnosti dostupného materiálu a súčasne aj neliterárnych zložitostí vo výkladoch o ich účinkovaní v hektickom minulom storočí. Štyri tak 
odlišné autorské dielne a vyhranené osobnosti prepojit do osobnostne strategického a genologického podložia si žiadalo utvorit možné javové východisko, ktorým autor publikácie reaguje na aktívnu tradíciu, kontext, politikum, kultúrnu politiku a osobnostnú výbavu autorov. Takto roztvorený záber predpokladá podporu v historiografii minulého storočia, čím sa zvýrazňuje tak potrebná konštrukcia vývinu dejín literatúry, dejín kultúry a dejín spoločnosti. Popri syntézach sú podnetné aj analýzy príčin a dôsledkov, ktoré sú odvodené z činností relevantných osobností slovenskej umeleckej a prekladovej spisby, ich kultúrnej aktivity a publicistiky v tak náročnom a názorovo aj postojmi nie vždy voči jednotlivcovi žičlivo otvorenom minulom storočí. Diskontinuita spoločenských dejov, ktoré reprezentujú dejiny politiky, ovplyvnila zásadným spôsobom, medzi inými, životné príbehy Mila Urbana, Jána Smreka, Jána Poničana, Tida J.(ozefa) Gašpara. Do retazca osobností s blízkymi osobnými aj tvorivými dejinami sa prirodzene radia, popri mnohých iných aj d’alších, Valentín Beniak či Emil Boleslav Lukáč aj preto, lebo ich osobnými aj autorskými dejinami prešli kultúrnopolitické a politické deje z prelomových tridsiatych až šestdesiatych desatročí rovnako ako v príbehoch Karolom Csibom spracovaných osobností. Problémový záber Csibovej publikácie možno považovat za literárnovednú výzvu do budúceho spracovávania literárnych, osobných, kultúrnych a spoločenských tlačí zahrnutých do žánrovej štruktúry memoára, denníka, záznamníka a do mozaiky publicistických výstupov d’alších osobností vyrovnávajúcich sa existenciálne a literárne $\mathrm{s}$ realitou a reáliami vôkol seba, a to aj vtedy, ked' ich dosah na konkrétnu autorskú tvorbu pre mnohých tvorivých literátov a publicistov bol zvlášt v štyridsiatych a pätdesiatych rokoch odlišný.

Autor publikácie si je vedomý toho, že pracuje s torzom a vynáša poučený verdikt na podloží torza ním zvolenej časti materiálu, ktorý má v sebe tú jedinečnost', že sa nebráni verifikácii iniciácie materiálom a záverom literárneho historika. Postup, čast za celok, dejiny literatúry za konkrétny literárny život konkrétneho autora sa vo svojej podstate mení na potrebnú poznávaciu sondu s rozšíreným záberom do dostupných poznatkov, ale popri tom vymedzuje aj limity aplikovanej literárnovednej metódy, ktorú zvolil Karol Csiba - lustrovanie materiálu, komentovanie ním komparovaných dokumentov a písomností, parafrázovanie, odkazy - a vo svojom výsledku poskytuje zaujatý výklad tej entity a zovšeobecnenej tézy, ktorú učebnice dejín literatúry alebo tradované postoje voči autorovi premenili na neopodstatnené, alebo tendenčné postoje, ak aj nie hned' zverejnené hodnotenia. Csibovo lustrovanie dokumentov, písomností, zverejnených textov sa ujme v procesoch literárneho vzdelávania, literárnej výchovy, pri monografických vertikálach do autorskej tvorby a prinesie zdôvodnený a doložitelný nový prístup $\mathrm{k}$ jednotlivcovi a jeho prostredníctvom ku generácii, druhu, látke a tematike, $\mathrm{k}$ nazeraniu na noetiku slovenskej vedy a kultúry. Oporou aj verdiktom vyslovených dobových súvislostí sa stali žánrovo odlišné výpovede štyroch autorov, literárna história prostredníctvom času dáva odpovede svojmu tvorcovi.

Odborná alebo čitatel'ská verifikácia zvolenej metódy a postupu, s ktorou Karol Csiba počíta ako s generačne novým prístupom $\mathrm{k}$ uchovaným alebo zverejneným reáliám, odkazuje na časti Subjekt ako obraz svedectva doby (tretia spomienková próza Mila Urbana) - (Na brehu krvavej rieky, 1994), Spomienky redaktora (druhá spomienková kniha Jána Smreka) - (Poézia moja láska 2, 1989), Spomienky Jána Poničana (Búrlivá mladost'. Spomienky I. 1920 - 1938) a na Gašparov útek $k$ dejinám (druhá spomienková kniha Tida J. Gašpara) - (Pamäti II., 2004). Sila slova neslabne, môže byt vytisnutá na okraj nových dejov, ale o svoje slovo sa tak, či tak prihlási a vyriekne svoj verdikt podporený časom zastúpeným odstupom, poznaním a rozvahou.

„... všetky druhy umenia majú súvislosti a spoločný prazáklad... “(Ivan Kadlečík)

Za iných okolností, v inom čase, by do publikácie Karola Csiba pribudla d’alšia autorská kapitola venovaná záznamom, zápisom, memoárom, 
rozpomienkam, publicistike. Ivan Kadlečík patrí do literárnej generácie (z tých najbližších Albin Bagin, Pavol Hrúz, Oleg Pastier), ktorá sa ujímala kultúrneho a literárneho života $\mathrm{v}$ šest'desiatych rokoch, absolvovala široký mediálny záber, v ktorom jej členovia po vysokoškolských štúdiách našli svoje pôsobiská v kultúre. V tejto súvislosti vyšlo velavravné o tom, čo bolo tam a vtedy Čitanie myslenia, podl’a Ivana Kadlečíka „je to román, ktorého protagonistami sú časopisy košický Krok 66 a 67 a martinské Matičné čitanie 1968 - 1970“ (s. 53). Politikum desatročia, aj tých, čo nasledovali po ňom, spôsobilo, že im pozície v literárnom a kultúrnom živote nepatrili nadlho a pravidlá nového spoločenského času rozhodli, že za zmenených okolností sa predsa len svojho vztahu $\mathrm{k}$ slovu a písaniu nevzdali, hoci im chýbal čitatel’ a kultúrna reflexia.

Azda nemôže byt príznakovejšie v spomenutej literárnovednej súvislosti zvolený názov pre besedy a besednice Ivana Kadlečíka ako Iskra v studenej pahrebe. Kadlečíkova noetika uložená, ale aj vyžadovaná od slova a tvorby smeruje k sentenciám: "literatúra je aj hladanie pravdy“ a pri nej „hovorím najradšej o tom, ̌́o zblizka poznám“ (s. 7). Do Kadlečíkovho registra morálky tvorby a morálky jej tvorcu sa zaradili svedomie, individuálna zodpovednost', zmysel bytia, spôsob myslenia, a to azda aj preto, ako napísal, lebo „Najradšej žijem teraz, ked' toto pišem, naplnený nekonečnom toho, čo bolo a čo ešte bude“ (s. 11).
Besedy a besednice sú svojím žánrom naklonené rozpomienkam na dobu, ludí, spôsoby, hodnoty, na umenie a osudy jednotlivcov, ale i na ten jeho, a kompozične ich v publikácii ukotvujú prológ uchopený ako literárny rozhovor Ludovíta Petraška s Ivanom Kadlečíkom a ako epilóg, rozhovor Alexandra Bologha s Ivanom Kadlečíkom pomenovaný Čest' nezávisí od toho, kol'ko je hodin. Nad rozpomienkami, zápiskami, sentenciami, filozofovaním sa pohybujú Kadlečíkove haiká ako dostredivé miesta na zachytenie emócie, senzuálneho dotyku s realitou, krásy slova a obdiv k prírode. A do nich, ako do skrinky pre dedičov autor uložil alarmujúci odkaz: ,... považujeme všetko mravné za nevýnosné a všetko výnosné za mravné..." (s. 22).

Dotyky s dokumentom, spojenectvo s autorom, príležitost̉ vrátit sa $\mathrm{k}$ tomu, čím jeho slovo oslovovalo svoju dobu, ale tá o to nestála, ved' doba, tu a teraz, ale aj dejiny, to sú ludia, rovnako ako blízkost' autorovho zvažovania osobného času, jeho vklad do toho, čím budú žit potomkovia, ked' budú stát o slovo, to všetko sa v literárnej vede uchováva spravidla pod značkou dobrá literatúra. Dobrou literatúrou nič nekončí, naopak začína sa hladanie podložia hodnoty myslenia, vedenia, pointovania, ale aj odkazov uložených do myslenia, filozofovania, do noetiky, či do pochybností a rozčarovaní tvorcu a jeho vykladačov znova z času a jeho obsahov. Večné panta rei si pýta odpovede, na tom sa nič nezmení.

\section{prof. PhDr. Viera Žemberová, CSc.}

Inštitút slovakistiky a mediálnych štúdií

Filozofická fakulta, Prešovská univerzita v Prešove

Ul. 17. novembra č. 1, 08001 Prešov, Slovensko

viera.zemberova@ff.unipo.sk 